\title{
PPARA Gene
}

National Cancer Institute

\section{Source}

National Cancer Institute. PPARA Gene. NCI Thesaurus. Code C91749.

This gene is involved in lig and-mediated transcriptional regulation. 